\title{
On primary and secondary movement
}

\author{
Saara Huhmarniemi \\ Institute of Behavioural Sciences, Cognitive \\ Science, University of Helsinki \\ saara.huhmarniemi@helsinki.fi \\ Pauli Brattico \\ Institute of Behavioural Sciences, Cognitive \\ Science, University of Helsinki \\ pauli.brattico@helsinki.fi
}

\begin{abstract}
Theories of $A^{\prime}$-movement can be classified on the basis of how they relate primary movement (movement to the final scope position) to secondary movement (intermediate movement). The standard view maintains that primary movement and secondary movement are motivated and triggered by different grammatical factors. For instance, it can be assumed that primary movement is what ultimately drives syntactic operations while secondary operations have a supporting auxiliary role and serve as a partial implementation of primary movement. Some recent hypotheses, such as Chomsky's edge feature (EF) hypothesis, have opened up the possibility of narrowing the gap between these two operations. Here we argue on the basis of Finnish wh-movement that there is no difference between primary and secondary $A^{\prime}$-movement; they have exactly the same triggers and constraints, in addition to having other properties in common. We develop a theory of $A^{\prime}$-movement that relies on a discourse-active edge feature at a phrase/phase head.
\end{abstract}

Keywords: Finnish; movement; pied-piping; successive-cyclic movement; edge feature

\section{Introduction}

This paper investigates the existence and motivation of two linguistic operations, primary movement and secondary movement. ${ }^{1}$ Whereas primary movement denotes the movement of an element to a position where it implements a definite grammatical function, secondary movement denotes the partial implementation of primary movement. Example (1) illustrates primary $\mathrm{A}^{\prime}$-movement.

${ }^{1}$ We thank the participants of the Biolinguistics seminar organised by the Cognitive Science unit at the University of Helsinki during 2012: Tommi Gröndahl, Jukka Purma, and Taija Saikkonen. For the first author, this work was supported by grants from the Ella and Georg Ehrnrooth Foundation and the Oskar Öflunds Stiftelse.

1216-8076/\$20.00 (C) 2013 Akadémiai Kiadó, Budapest 
(1) Who did John believe that Mary saw _ ?

In this example, the wh-element marks both the scope of the interrogative at the interrogative matrix $\mathrm{C}$ and the constituent that has been questioned, here the object of the verb see. Using this as a background, consider (2).

(2) Through which city does the Seine run _?

What moves here is not a wh-word but a prepositional phrase that contains the $w h$-element. In the terminology of Ross (1967), the wh-element pied-pipes the containing constituent. This means that two grammatical domains interact to yield the attested forms: primary sentential domain $\alpha$, which involves movement of the wh-element to the final scope position, and secondary subsentential domain $\beta$, which constitutes the phrase that is raised. This is illustrated in (3).

(3) $\left[\alpha[\beta\right.$ Through which city $]$ does the Seine run $\left.\_\right]$?

In English, the wh-element stays in situ within the pied-piped PP. This, however, is not the general pattern. Several languages follow an edge generalization, which states that the wh-element must occur at the left edge of the secondary domain (Heck 2004; 2008). For instance, in a series of recent publications, Huhmarniemi $(2009 ; 2012 ; 2013)$ demonstrates that the edge generalization holds for Finnish. ${ }^{2}$ An equivalent to (2) in Finnish would therefore be (4a), while the version (4b), which leaves the interrogative at the complement of $\mathrm{P}$, is ungrammatical (unless interpreted as an echo-question). On the other hand, if the DP-argument is not an interrogative (or some other element that triggers movement), it may occur in the complement of $\mathrm{P}$, as in (4c).

(4) a. [Minkä kaupungin läpi] Seine virtaa?

which city through Seine runs

'Through which city does the Seine run?'

\footnotetext{
${ }^{2}$ Finnish is a Finno-Ugric language characterised by agglutinative morphology: it has fifteen case suffixes and full phi-agreement on finite verbs, non-finite verbs, nouns, adjectives and even on prepositions. Finnish does not have obligatory overt articles. Demonstrative pronouns and the pronoun se, 'it', are often used in place of determiners. The basic word order is SVO. With respect to $w$-movement, Finnish patterns with English: one wh-element is required to move to the left periphery, while the other wh-phrases remain in situ (Hakulinen \& Karlsson 1979, 283). For an overview of Finnish clause structure, see Holmberg \& Nikanne (2002).
} 


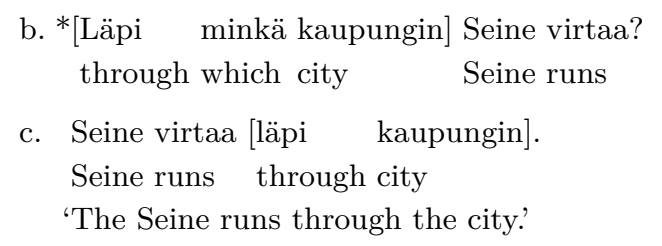

This brings us to secondary movement. It is often assumed that there is a distinct movement step which brings the wh-element to the left periphery of its secondary domain. Schematically, this comes to the following:

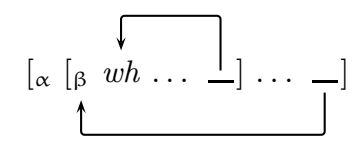

Secondary movement can be viewed as part of a sequence of operations implementing primary movement. This view now raises the question of whether the primary operation that brings the wh-element to its final position (move- $\beta$ ) and the sub-operation(s) (move-wh) are based on two distinct mechanisms, or whether they are manifestations of the same mechanism. As we will discuss below, many authors who agree on little else share such a "demarcation hypothesis" stating that the two movement steps are based on two distinct (perhaps overlapping) operations (Chomsky 1973; Riemsdijk 1985; Cowper 1987; Webelhuth 1992; Grimshaw 2000; Cable 2010a;b). In contrast, there are others who have proposed a more homogeneous treatment, according to which the difference between primary and secondary movement is either nonexistent or very small (Rizzi 1997; Chomsky 2008; Heck 2008; 2009). This debate strikes at the very heart of $\mathrm{A}^{\prime}$-movement, as it addresses why $\mathrm{A}^{\prime}$-movement exists and how its properties should be explained.

In this paper, we argue for the latter position. We do so by examining secondary movement within Finnish pied-piped phrases. We conclude that there is in fact no primary and secondary movement: secondary movement is subsentential primary movement. We examine all the most important properties attributed to primary movement and show that the same properties apply to secondary movement. The conclusion then follows on the grounds that it makes little sense to draw a line between two sets of processes that are identical in their properties. ${ }^{3}$ Following this line of

\footnotetext{
${ }^{3}$ McCloskey (2002) argues for the same point, but only in connection with successive-cyclic movement. We return to this issue later on.
} 
thought, we propose an equivalence principle, Primary/Secondary Equivalence, which states this condition explicitly.

This article is organised so that section 2 provides the theoretical background from which we approach $\mathrm{A}^{\prime}$-movement and section 3 enumerates the parallels between primary and secondary domains in Finnish. Section 4 provides a discussion of the present findings and section 5 concludes the paper. In brief, our argument that primary and secondary domains behave in an identical fashion is made possible by the fact that Finnish obeys the edge generalization (Heck 2008) in a vast number of constructions (e.g., non-finite clauses, PPs, DPs), allowing us to investigate how movement to the edge performs under diverse conditions. That is, given some property that regulates primary movement it is nearly always possible to find a context in Finnish where the same property can be tested against secondary movement. We will document the following parallels between primary and secondary domains: both movement types obey an edge principle and c-command, and both of them leave a gap; they are triggered by the same properties, involve pied-piping, and obey island constraints. Furthermore, both of these movement types cause an echo-interpretation with the $w h$-in situ strategy, reconstruction in reflexive binding, scope interaction, weak crossover, a form of resumptive construction and parasitic gapping. Finally, the assumption that primary and secondary domains are operated by the same cross-categorial $\mathrm{A}^{\prime}$-movement module solves the lookahead problem and is supported by considerations from parsimony.

\section{Primary and secondary movement}

Before we look at the data, we will provide a more detailed roadmap for the theories of secondary movement and how we intend to navigate amongst them here. There are two types of secondary movement, successive-cyclic movement that does not trigger pied-piping and another form which does trigger pied-piping. Example (6) illustrates successive-cyclic movement via an intermediate landing site at the edge of CP.

(6) What does he think — that Mary saw _?

These two secondary movement types are treated somewhat differently in current linguistic theories. One reason is that the secondary movement that comes with pied-piping is overt: the moved element does not escape the pied-piped phrase, and so we can directly see its presence at the edge 
of that phrase. In contrast, if the wh-element escapes the phrase, it leaves only indirect traces of its pit-stop at the edge.

Pied-piping has been a subject of inquiry since its popularization by Ross (1967). One of the earliest accounts of pied-piping is referred to as "feature percolation". In feature percolation, the wh-feature of the wh-phrase is transferred to the top of the containing constituent, making the constituent a goal for primary movement (Chomsky 1973; Cowper 1987; Webelhuth 1992; Grimshaw 2000); for an overview, see Horvath (2006, ch. 1) and Heck (2008). We are interested in whether wh-feature percolation and primary wh-movement are based on exactly the same operation, or whether they differ in some respects. The standard assumption in the literature cited above and elsewhere is that they are not the same operation; hence the distinct labels. Theories concerning the former have been developed relatively independently of the theories concerning the latter. For instance, the movement of the wh-phrase to the edge of the piedpiped phrase might be considered as a distinct operation which merely facilitates feature percolation (e.g., Kayne 1994; Horvath 1997; Koopman $\&$ Szabolcsi 2000). In addition, the $w h$-in situ phenomenon has been theorised differently depending on whether it concerns primary movement or secondary movement. Thus, such theories posit a demarcation between primary and secondary operations.

The problems of feature percolation are at present well-known, and some recent approaches to pied-piping, most notably the Agree-based analysis of Heck $(2008 ; 2009)$ and the Q-based analysis of Cable (2010b), seek to eliminate this operation from grammar. ${ }^{4}$ However, in other respects, these two models approach pied-piping and secondary movement phenomena from different viewpoints. In the Agree-based analysis of Heck (2008; 2009), movement operations arise from the requirement for the Agreerelation between the $w h$-element and the probing interrogative $\mathrm{C}$ to be maximally local. In wh-questions that involve pied-piping, the most optimal derivation involves the least amount of phrase boundaries between the $\mathrm{C}$ and $w h$-element. For instance, the least amount of phrase boundaries is created when the wh-element moves alone to the specifier of $\mathrm{C}$. This locality condition triggers secondary movement to the edge of the island phrase

\footnotetext{
${ }^{4}$ The main problem of the feature percolation approach according to Heck and Cable is that an operation that transfers features of some head $H$ to projections outside its own projection without following the constraints that are typically imposed on grammatical operations (Merge, Agree and Move) is too special. This is also signaled by the fact that feature percolation fails to generalize to other domains of syntax.
} 
that restricts $w h$-movement. Movement of the $w h$-phrase effectively shortens the distance between the C-probe and wh-goal. Heck's model therefore reduces all movement to the same locality condition on Agree. In addition, each movement step is driven or triggered by the interrogative $w h$-feature of C. ${ }^{5}$ This model does not draw a strong demarcation between primary and secondary movement: both movement types try to shorten the distance between the C-probe and the wh-goal and both are triggered by the wh-C.

In the Q-based analysis of Cable (2010a;b), in contrast, the goal element of the interrogative probe $\mathrm{C}$ is not the wh-feature of the wh-phrase but, instead, the question particle $\mathrm{Q}$ that heads the pied-piped phrase that contains the wh-element. Wh-movement to the C-domain is triggered by the Q-particle, not the $w h$-phrase itself. Secondary domains do not involve the same mechanism. Instead, the Q-particle Agrees with the wh-phrase within its domain, and the conditions of Agree facilitate secondary movement of the $w h$-phrase. This means that primary and secondary movement have distinct triggering mechanisms and a distinct motivation. Cable thus promotes a version of the demarcation hypothesis.

Another instance of secondary movement is successive-cyclic movement: an element occupies one or more intermediate landing sites on its way to the final scope position but does not trigger pied-piping, as was illustrated in example (6) above. The intermediate movement steps are often seen as having a secondary role in implementing the movement to the final landing site. However, McCloskey (2002) approaches successive-cyclic movement by proposing a mechanism where (1) all movement steps are feature-driven and (2) they are driven by almost the same features. Intermediate features are uninterpretable "pseudo" versions of the full features. This hypothesis is adopted in Rizzi (2006), who proposes that "intermediate movement is driven by features that are the purely formal counterpart of substantive criterial features" (op.cit., 111). The features that trigger primary and secondary movement are therefore almost the same. This being so, can the distinction be eliminated entirely? As we understand it, Chomsky (2008) indeed eliminates the distinction in its entirety by proposing that movement is just an "internal" variant of Merge, everywhere triggered by the edge feature (EF). According to Chomsky (regarding topicalization movement), "what is raised is identified as a topic by the final position it reaches, and any extra specification is redundant" while

${ }^{5}$ Technically this is achieved by allowing the derivation to "see" the presence of the $w h-\mathrm{C}$ in the numeration. 
all this "could be true for other forms of A'-movement" (op.cit., 151). It is not, in other words, topicalization or interrogativization which triggers movement; these properties are the outcome of the operation.

In sum, there is currently some controversy over whether secondary movement is identical in all or most of its properties to primary movement, or whether they should be examined as two distinct operations. There is a straightforward way to put these propositions to empirical test. If there were a language where the properties of secondary movement could be directly observed in a wide variety of constructions, it could be possible to compare primary movement and secondary movement with respect to any relevant property one can imagine. Finnish is such language. Hence, we will look at all relevant properties of primary movement and set up experiments for secondary movement to tease out their differences. As it turns out, we failed to find any. Therefore, we will argue in favor of a fully unified theory of $\mathrm{A}^{\prime}$-movement. To this end, we put foward (7), which asserts that all theorizing that applies to primary domains should apply, without further ado, to secondary domains, and vice versa. ${ }^{6}$

(7) Primary/Secondary Equivalence

Primary movement $=$ secondary movement

By equivalence we mean that there is no empirical motivation for postulating a different mechanism for primary movement and secondary movement. ${ }^{7}$ Primary/Secondary Equivalence includes the triggers: Finnish data show that both movement types are triggered by the same reasons and by the same features.

One common assumption shared by unified theories (e.g., Chomsky 2008) and dual theories (e.g., Cable 2010b) is that secondary movement is movement. Furthermore, it is commonly held that both movement types are instances of $\mathrm{A}^{\prime}$-movement. Part of our argumentation will provide strong support for this contention: we will show that all $\mathrm{A}^{\prime}$-movement-diagnostics, such as weak crossover, apply to secondary movement as much as to primary movement. But what is at stake here is a stronger hypothesis. We wish to claim that exactly the same triggers, the same motivation

${ }^{6}$ Similar propositions have been previously examined. Chomsky (1977) argued that a wide variety of constructions exhibit the same wh-movement system. Several hypotheses have attempted to unify the Case module, for instance, so that all structural Case assignment is based on the Spec-Head mechanism (Chomsky 1993).

${ }^{7}$ Perhaps it goes without saying that Primary/Secondary Equivalence is intended to be read in the de re mode (like "Evening Star = Morning Star" and other empirical identity claims). 
or function, the same constraints and the same basic operations underlie both phenomena; indeed, that there is no distinction between primary and secondary movement. Accordingly, we would like to claim that Universal Grammar does not recognise any difference between the two.

\section{Parallelisms between the two types of movement in Finnish}

\subsection{The properties of edge positions and c-command}

In this section we document the parallels between primary and secondary movement. We begin by analysing the two most central properties of primary movement. The first property says that the landing site of the wh-element must c-command its trace position. The second property says that the wh-element must land at a left peripheral position of a finite clause, such as Spec-C. Let us call this final position the edge position. The architecture of primary movement is illustrated in (8).

(8) Who did John believe that Mary saw _?

Edge Gap

The wh-element has moved to a left-peripheral edge position of the finite clause (labelled "Edge") from its base position, which is silenced (labelled "Gap"). The edge position c-commands its trace position. Further $w h$-movement ceases when the wh-element reaches the criterial position. These properties also characterize secondary movement. A wh-element inside a DP (9a), PP (9b) or an adverbial clause (9c) must appear at the leftmost position of its respective domain, thus at Spec-D, Spec-P and Spec-Adv, respectively. Moreover, the wh-element c-commands the trace position. $^{8}$

\footnotetext{
${ }^{8}$ We use the following abbreviations in this article: $-h A n$ and $-p A=$ left-peripheral focus particles, $-k O=$ a left-peripheral question particle. Non-finite verb forms that appear in adverbial clauses are glossed as follows: $\mathrm{KSE}=$ 'in order to do something', ESSA = 'while doing', TUA = 'after doing', $\mathrm{E}=$ 'while doing', MATTA $=$ 'without doing' and MALLA = 'by (means of) doing something'. Finnish has two structural object cases, $\mathrm{ACC}=$ accusative and $\mathrm{PAR}=$ partitive. Other cases that appear in glosses are $\mathrm{NOM}=$ nominative, GEN $=$ genitive, $\mathrm{ELA}=$ elative and ILL $=$ illative. Finally, PX = agreement inflection (possessive suffix) and Spec-H = specifier position of the head $\mathrm{H}$, in the sense of the $\mathrm{X}^{\prime}$-theory.
} 
(9) a. [DP Kenen kahta _ koiraa] Pekka hoiti?

whose two-PAR dog-PAR Pekka-NOM looked after

'Whose two dogs did Pekka look after?'

b. $\left[\text { PP Mitä } \ddot{\text { a }}_{i} \text { kohti }{ }_{i}\right]_{j}$ he matkustivat ${ }_{j}{ }$ ?

what-PAR towards they-NOM travelled

'What did they travel towards?'

c. $\left[\operatorname{AdvP} \text { Mitä }_{i} \text { tarinaa kertoessaan }-i\right]_{j}$ he unohtivat ajankulun $-_{j}$ ? which-PAR story-PAR tell-ESSA-PX they-NOM forgot time-ACC

lit. 'While telling which story did they forget the time?'

'Which story were they telling when they forgot the time?'

Data in $(9 \mathrm{a}-\mathrm{c})$ contrast with $(10 \mathrm{a}-\mathrm{c})$, where the $w h$-element is substituted by an ordinary DP. Note that all movement steps are cancelled, as in $(10 \mathrm{a}-$ c). If these examples contained $w h$-phrases at the positions of these DPs, they would be interpreted as echo questions.

(10) a. Pekka hoiti [DP kahta naapurin koiraa].

Pekka looked after two-PAR neighbour's dog-PAR

'Pekka looked after the neighbour's two dogs.'

b. He matkustivat [PP kohti Seineä].

they-NOM travelled towards Seine-PAR

'They travelled towards the Seine.'

c. He unohtivat ajankulun [AdvP kertoessaan tarinaa].

they-NOM forgot time-ACC tell-ESSA-PX story-PAR

'They forgot the time while telling a story.'

The existence of an edge position within the secondary domain is supported by the fact that the left periphery of Finnish finite clause contains only one position for discourse-related movement (Vilkuna 1989; 1995; Vainikka 1989) (see also examples (13a-c) below). This rules out any possibility that the pied-piping in the above examples would be composed of two distinct movement steps. In other words, it is possible to exclude the hypothetical derivation illustrated in (11a-b): in (a), the DP is extracted from the PP, and in (b), the PP undergoes remnant movement to the edge of CP.

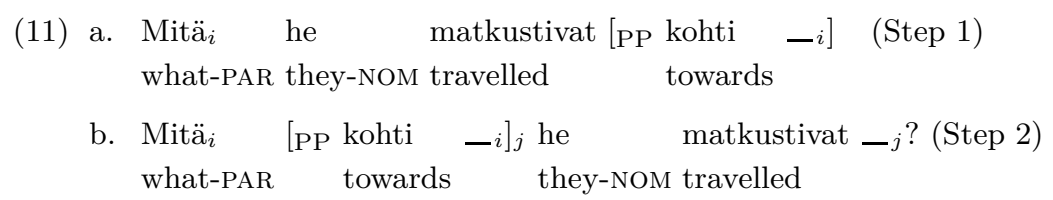


The presence of only one edge position effectively blocks the movement of two distinct constituents to the left periphery. For instance, in (12b), the direct object argument has moved to the edge of CP. Example (c) shows that fronting the PP is then impossible. Furthermore, in many occurrences of secondary movement and pied-piping, the moved phrase is an extraction island and, therefore, sub-extraction would constitute an island violation (see also the discussion in Huhmarniemi 2012, 214).

(12) a. He käänsivät auton [PP kohti kaupunkia]. they-NOM turned car-ACC towards city-PAR

'They turned the car towards the city.'

b. Minkä ${ }_{i}$ he käänsivät ${ }_{i}{ }$ [PP kohti kaupunkia]?

what-ACC they-NOM turned towards city-PAR

'What did they turn towards the city?'

c. ${ }^{*}{ }^{\text {Minkä }}{ }_{i} \quad[\mathrm{PP} \text { kohti kaupunkia }]_{j}$ he käänsivät $-^{i}-_{j}$ ?

what-ACC towards city-PAR they-NOM turned

A further observation which supports the existence of edge-positions within secondary domains is the following. The movement to the edge suppresses elements which would otherwise occupy the same position regardless of the domain (Huhmarniemi 2012, 213). Finnish being a single wh-fronting language, the edge position of a finite clause can be filled with only one element at a time (Hakulinen \& Karlsson 1979, 283). This is shown in $(13 \mathrm{a}-\mathrm{c})$.

(13) a. Kenet ${ }_{i}$ Pekka näki $-_{i}$ milloin?

who-ACC Pekka-Nom saw when

'Whom did Pekka see when?'

b. ${ }^{*}$ Kenet $_{i} \quad$ milloin $_{j}$ Pekka näki $-_{i}{ }_{j}$ ?

who-ACC when Pekka-NOM saw

'*Whom when did Pekka see?'

c. ${ }^{*}$ Milloin $_{j}$ kenet $_{i} \quad$ Pekka näki $-i{ }{ }^{j}$ ?

when who-ACC Pekka-NOM saw

'*When whom did Pekka see?'

In addition, head movement to the projection that hosts the edge position suppresses phrasal movement to the same projection. Head movement may be triggered by discourse particles, such as the question particle $-k O$ in the examples below. Example (14b) shows that head movement to the left periphery blocks phrasal movement in a finite clause (see also Vilkuna 1989; Vainikka 1989). 
(14) a. On-ko Pekka _ lähtenyt kotiin?

is- $k O$ Pekka-NOM left home.to

'Has Pekka gone home?'

b. *Mihin on-ko Pekka _ lähtenyt _ ?

where is- $k O$ Pekka-NOM left

The third instance of the blocking effect in primary domains is caused by adverbs. For example, the adverb nyt 'now' occupies the edge of $\mathrm{CP}$ in example (15a) and blocks wh-movement in example (b). ${ }^{9}$

(15) a. Nyt Pekka lähtee kotiin.

now Pekka-NOM leaves home.to

'Now Pekka goes home.'

b. *?Mihin nyt Pekka lähtee _ ?

where now Pekka-Nom leaves

Similar examples are available for secondary domains. In (16a), the edge of DP is filled with a question phrase, which suppresses wh-movement of the possessor in (16b).

(16) a. [DP Montako naapurin _ koiraa] Pekka hoiti? how many neighbour's dog-PAR Pekka-NOM looked after

'How many of the neighbour's dogs did Pekka look after?'

b. *[DP Kenen montako _ koiraa $]$ Pekka hoiti?

whose how many dog-PAR Pekka-NOM looked after

‘*Whose how many dogs did Pekka look after?'

Furthermore, the presence of an overt demonstrative pronoun at the left edge of a DP (the D-head) blocks DP-internal wh-movement in $(17 \mathrm{a}-\mathrm{c})$. In this case, the presence of an overt head suppresses movement to the same projection. An overtly filled head position thus interacts with phrasal movement to the specifier position in both primary and secondary domains in Finnish.

(17) a. Sinä kannoit [näitä Merjan matkalaukkuja].

you-NOM carried these-PAR Merja's suitcases-PAR

'You carried these suitcases of Merja.'

b. *[Näitä kenen matkalaukkuja] sinä kannoit _?

these-PAR whose suitcases-PAR you-NOM carried

'*These whose suitcases did you carry?'

${ }^{9}$ We thank Anders Holmberg (p.c.) for pointing this out. 


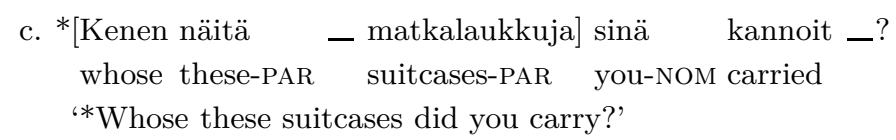

Finally, in a comparable way to the primary domain in examples (15), certain adverbs fill in the edge position of PPs and block wh-movement. This is illustrated in the examples in (18) (see also Huhmarniemi 2012, 107108). First, example (18b), in which the adverb precedes the wh-phrase, is an echo question (echo questions do not involve overt wh-movement in Finnish). On the other hand, wh-movement past the adverb in (c) is impossible.

(18) a. Pekka otti kurssin [suoraan kohti lentokenttää].

Pekka-NOM took course-ACC straight towards airport-PAR

'Pekka took a course straight towards the airport.'

b. [Suoraan mitä kohti _] Pekka otti kurssin -?

straight what-PAR towards Pekka-NOM took course-ACC

'Pekka took a course straight towards what?'

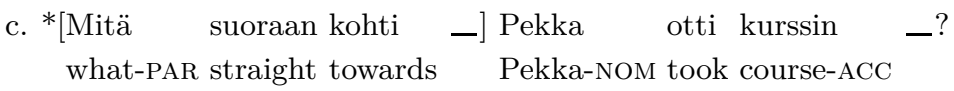

Heck $(2008,88-105)$ presents evidence that the edge generalization is attested in several languages in addition to Finnish. In conclusion, both primary and secondary movement targets the left edge of the next relevant phrase ${ }^{10}$ above and both operations leave an empty position, a gap, behind. Finally, movement is blocked if the edge position is filled.

\subsection{Triggers}

Primary $\mathrm{A}^{\prime}$-movement to the left periphery of a finite clause can be triggered by several features. In Finnish, the moving elements are wh-phrases (19a), relative pronouns $(19 \mathrm{~b})$ and elements which have been affixed with the question particle $-k O(19 \mathrm{c})$ or the focus particles $-h A n /-p A(19 \mathrm{~d}-\mathrm{e}) \cdot{ }^{11}$

${ }^{10}$ In this article we only enumerate what these "relevant" phrases are. Brattico (2012c) argues that they are characterized by adjoinability, a property which licenses the use of the said phrases in an adjunct position.

${ }^{11}$ For the second position focus particles/clitics in Finnish, see Nevis (1988). In addition, an element may be raised to the edge of CP in Finnish without any special marking, in which case it obtains a contrastive focus. 
(19) a. Minkä tarinan Pekka kertoi _?

which-ACC story-ACC Pekka-NOM told

'Which story did Pekka tell?'

b. tarina, jonka Pekka kertoi -

story which-ACC Pekka-NOM told

'a/the story that Pekka told'

c. Tarinan-ko Pekka kertoi _ ?

story-ACC- $k O$ Pekka-NOM told

'Was it a story that Pekka told?'

d. Tarinan-han Pekka kertoi story-ACC- $h A n$ Pekka-NOM told

'It was a story that Pekka told.'

e. Tarinan-pa Pekka kertoi _ !

story-ACC- $p A$ Pekka-NOM told

'It was a story that Pekka told (not a joke, as you claim).'

The same morphemes/features trigger secondary movement. This is shown in the following for a DP (20), PP (21) and for an adverbial clause (22). The moved element is marked morphologically as a wh-element in (a), as a relative pronoun in (b), it receives a discourse particle $-k O$ in (c) and $-h A n$ in $(\mathrm{d})$.

(20) Determiner phrase

a. [Mihin muuttamista _] sinä odotat _?

where.to moving-PAR you-NOM wait

'Where are you waiting to move to?'

b. kaupunki, [johon muuttamista _] sinä odotat city where.to moving-PAR you-NOM wait

'a/the city where you are waiting to move to'

c. [Kaupukiin-ko muuttamista _ ] sinä odotat _? city.to- $\mathrm{O} O$ moving-PAR you-NOM wait

'Is it moving to the city that you are waiting for?'

d. [Kaupunkiin-han muuttamista _ ] sinä odotat _! city.to- $h A n$ moving-PAR you-NOM wait

'It is moving to the city that you are waiting for.'

(21) Prepositional phrase

a. [Mitä kohti _ $]$ sinä heitit pallon _? what-PAR towards you-NOM threw ball-ACC 'What did you throw the ball towards?' 
b. ikkuna, [jota kohti _ ] sinä heitit pallon window which-PAR towards you-NOM threw ball-ACC 'a/the window that you threw the ball towards'

c. [Kaupunkia-ko kohti _-] me matkustetaan _ ? city-PAR- $k O$ towards we-NOM travel 'Is it the city that we are travelling towards?'

d. [Kaupunkia-han kohti _-] me matkustetaan _ ! city-PAR- $h A n$ towards we-NOM travel 'It is the city that we are travelling towards!'

(22) Adverbial clause

a. [Mitä vitsiä kertoessaan _ ] isä nukahti _ ? which-PAR joke-PAR tell-ESSA-PX father-NOM fell.asleep 'Which joke was the father telling when he fell asleep?'

b. Vitsi, [jota kertoessaan _] isä nukahti joke which-PAR tell-ESSA-PX father-NOM fell.asleep 'The joke that the father was telling when he fell asleep.'

c. [Tarinaa-ko kertoessaan _] isä nukahti _? story-PAR- $k O$ tell-ESSA-PX father-NOM fell.asleep 'Was it a story that the father was telling when he fell asleep?'

d. [Tarinaa-han kertoessaan _] isä nukahti _! story-PAR- $h A n$ tell-ESSA-PX father-NOM fell.asleep

'It was a story that the father was telling when he fall asleep.'

As outlined in the introduction, leaving the relative pronoun in situ within the pied-piped phrase leads to an ungrammatical sentence, and the in situ wh-phrase forces an echo reading. However, the discourse particles display an additional movement strategy, where the particle can be left in situ within the pied-piped phrase. Example (23) below illustrates that the $-k O$ particle does not have to occupy the edge in order to pied-pipe (see also Holmberg in press).

(23) Merjan kaupukiin-ko muuttamista] sinä odotat _?

Merja's city.to- $k O$ moving-PAR you-NOM wait

'Is it Merja's moving to the city that you are waiting for?'

The in situ phrase that hosts the $-k O$-particle typically requires prosodic emphasis in order to be licensed, whereas no such emphasis is required for the element at the edge of the pied-piped phrase. This in situ strategy is an exceptional phenomenon in Finnish, and the movement alternative 
exemplified in (20)-(22) represents the general pattern for the second position clitic particles. We will assume here that the in situ strategy requires the presence of an additional discourse feature that is able to prevent the movement within the secondary domain.

All in all, the data presented in this section suggest that primary and secondary movements are triggered by the exact same features. We interpret this observation literally and claim that, unless a difference in the triggering features is demonstrated, the theory of $\mathrm{A}^{\prime}$-movement should treat them in a unified fashion.

\subsection{Pied-piping}

It is well-known that primary movement may involve pied-piping and that pied-piping may occur in recursive fashion. This is illustrated in (24), where a PP that contains the wh-phrase moves to the edge of a finite clause. In this example, pied-piping occurs through two phrase layers. These constructions are examples of "recursive pied-piping", discussed recently by Heck (2008). Recursive pied-piping does not necessarily require movement within the secondary domain, as we see below.

(24) [PP Through [DP which city]] does Seine run?

Here, we are interested in whether pied-piping is a property of secondary movement. In the following, we consider examples of primary movement that involve pied-piping and then show that the same phenomenon takes place in secondary movement. Consider first the examples under (25). In (25a), the possessor occupies the edge of an object DP and pied-pipes the DP to the edge of the finite clause. In (25b), the wh-argument of the prepositional head occupies the edge and pied-pipes the containing PP.

(25) a. [DP Kenen kaksi — lempitarinaa] Pekka kertoi _?

whose two favourite-story-PAR Pekka-NOM told

'Whose two favourite stories did Pekka tell?'

b. [PP Mitä kohti _ $]$ Pekka matkusti _?
what-PAR towards Pekka-Nom travelled

'What did Pekka travel towards?'

The same pied-piped phrases also undergo pied-piping within secondary domains, such as DPs and adverbial clauses. In (26a), the possessor DP itself contains a wh-possessor, which pied-pipes the DP to the edge of the 
secondary domain. Example (26b) shows how a $w h$-argument pied-pipes a $\mathrm{PP}$ to the edge of a DP.

(26) a. [[DP Kenen lempinäytelmän] kolme — näytöstä] Pekka peruutti _? whose favourite play's three act-PAR Pekka-NOM cancelled

'Whose favourite play's three acts did Pekka cancel?'

b. [[PP Mitä kohti _ ] matkustaminen _ ] oli huono ajatus? what-PAR towards travelling-NOM was bad idea

'What was it a bad idea to travel towards?'

Both phrase types undergo pied-piping within adverbial clauses. In (27a), the DP containing a wh-possessor is pied-piped to the edge of an adverbial clause, and example (27b) shows pied-piping of the PP within the secondary domain.

(27) a. [[DP Kenen kaksi — lempitarinaa] kerrottuaan _] Pekka nukahti _? whose two favourite-story-PAR tell-TUA-PX Pekka-NOM fell.asleep lit. 'After telling whose two favourite stories did Pekka fall asleep?' 'Whose two favourite stories did Pekka tell before falling asleep?

b. [[PP Mitä kohti _ ] matkustaessaan _ ] Pekka tapasi Merjan _? what-PAR towards travel-ESSA-PX Pekka-NOM met Merja-ACC

'Towards which city was Pekka travelling when he met Merja?'

Heck (2008) shows that recursive pied-piping is a crosslinguistically robust phenomenon. Finnish exhibits an impressive amount of recursive piedpiping combined with secondary movement. Finnish data therefore support the proposal by Heck (2008) that secondary movement to the phrase-edge may involve pied-piping. ${ }^{12}$

12 The question arises of whether the mechanism for pied-piping is the same in both primary and secondary movement domains. According to Cable (2010b), piedpiping to the final scope position is phrasal movement of a QP that is headed by the question particle Q. Assuming that wh-questions involve only one Q-particle, pied-piped structures would then have a different implementation in secondary domains (for discussion, see Cable 2010b, 230-231). This proposal receives support from languages such as Chol (Mayan) that do not display pied-piping in secondary movement (Coon 2009). On the other hand, the evidence from Finnish suggests the contrary, at least for this language. We thank Fabian Heck for raising this issue. 


\subsection{Movement constraints and interpretation}

\subsubsection{Island constraints in both domains}

Primary movement is restricted by island constraints. We show that island constraints, such as adjunct islands and the Left Branch Condition (Ross 1967), regulate secondary movement. Let us start with adjunct islands: it is not possible to move a wh-phrase out of a PP-adjunct in $(28 \mathrm{a}-\mathrm{b})$.

(28) a. Pekka pakkasi [PP matkaa varten].

Pekka-NOM packed journey-PAR for

'Pekka packed for the journey.'

$\begin{array}{lll}\text { b. }{ }^{*} \text { Mitä Pekka pakkasi }[\mathrm{PP}-\text { varten }] \text { ? } \\ \text { what-PAR } & \text { Pekka-NOM packed } & \text { for }\end{array}$

To examine the islandhood of the PP in nominal contexts, consider example (29a). This example contains a contrastively focused noun phrase that is modified by the same PP that appeared in the examples above. The wh-phrase cannot be moved out of the PP in the secondary domain (29b); the only way to form a content question is to pied-pipe the PP along with the $w h$-phrase to the edge (29c).

(29) a. Pekka lopetti [DP pakkaamisen [PP matkaa varten]].

Pekka-NOM finished packing-ACC journey-PAR for

'Pekka finished packing for the journey.'

b. *[Mitä matkaa pakkaamisen [PP — varten] Pekka lopetti _ ? which-PAR journey-PAR packing-ACC for Pekka-NOM finished

c. [[pP Mitä matkaa varten] pakkaamisen _ ] Pekka lopetti _ ? which-PAR journey-PAR for packing-ACC Pekka finished 'Which journey did Pekka finish packing for?'

Finnish does not allow possessor extraction in primary domains, as illustrated in $(30 \mathrm{a}-\mathrm{b})$.

(30) a. Pekka hoiti [DP naapurin koiraa].

Pekka-NOM looked after neighbour's dog-PAR

'Pekka looked after the neighour's dog.'

b. *Kenen Pekka hoiti [DP - koiraa $]$ ?

whose Pekka-NOM looked after dog-PAR

'*Whose did Pekka look after dog?'

As seen in example $(9 a) /(31 b)$, the possessor may undergo movement within a DP. 


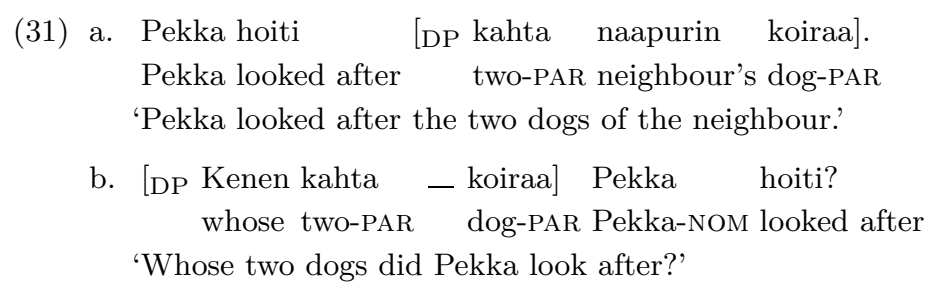

This movement obeys the same Left Branch Condition as movement in the primary domain. In (32a), the possessor is modified by another DP, which cannot be extracted out of the possessor in this secondary domain (32b). Again, a wh-question is created by pied-piping the possessor to the edge of the DP, as in (c).

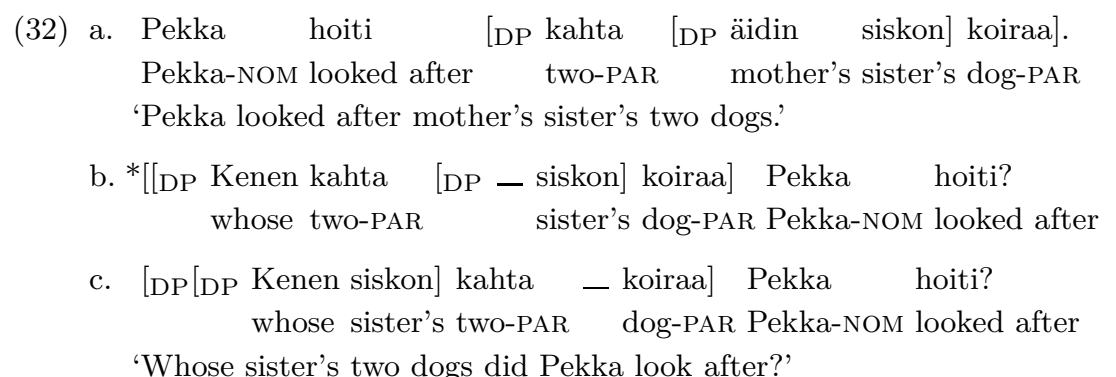

Secondary movement, like primary movement, is regulated by island constraints. The following generalization holds true for all the evidence we have seen: if there is an island boundary that blocks primary movement, then the same boundary will block secondary movement, and vice versa.

\subsubsection{Lack of movement in echo questions}

Often when primary wh-movement fails to occur, the sentence does not obtain interrogative force and is interpreted as an echo question. Echo questions typically repeat the previous utterance replacing the questioned part with a wh-element. In Finnish, echo interpretation arises when the wh-phrase does not occupy the edge of C. However, the echo interpretation is in Finnish also created when secondary movement fails to occur. Examples $(33 \mathrm{a}-\mathrm{c})$ (repeated from (4)) show how the lack of secondary movement produces an echo reading for the $w h$-phrase. Example (33a) is a standard interrogative that does not invoke echo-reading. Example (33b) shows that an echo-interpretation is forced if the PP is left in situ. Finally, in (33c), the PP occupies the edge of $\mathrm{CP}$, but PP-internal secondary wh-movement has not occurred. Here, too, an echo-interpretation is generated. 
(33) a. [Minkä kaupungin läpi _ _ Seine virtaa _? which-GEN city-GEN through Seine-NOM runs

'Through which city does the Seine run?'

b. Seine virtaa [minkä kaupungin läpi - $]$ ?

Seine-NOM runs which-GEN city-GEN through

'The Seine runs through which city?'

c. [Läpi minkä kaupungin] Seine virtaa _?

through which-GEN city-GEN Seine-NOM runs

'The Seine runs through which city?"

The absence of the interrogative interpretation in (33c) above can be verified with semantic selection tests. In Finnish, the verb väittää, 'claim', takes an assertive clause as its complement, as in (34a), and example (34b) shows that this verb cannot select an interrogative complement. However, if the complement clause forms an echo-question, as in (34c), a grammatical sentence results. The same is true in (d), which involves primary wh-movement but no secondary $w h$-movement within the fronted PP. ${ }^{13}$ These examples thus demonstrate that the embedded clause (34d) does not have the interrogative force that would prevent the selectional relation between the verb and the embedded clause.

(34) a. Pekka väitti että Seine virtaa [Pariisin läpi].

Pekka-NOM claimed that Seine-NOM runs Paris-GEN through

'Pekka claimed that the Seine runs through Paris.'

b. ${ }^{*}$ Pekka väitti että [minkä kaupungin läpi _ $]$ Seine virtaa. Pekka-NOM claimed that which-GEN city-GEN through Seine-NOM runs

c. Pekka väitti että Seine virtaa [minkä kaupungin läpi _]? Pekka-NOM claimed that Seine-NOM runs which-GEN city-GEN through 'Pekka claimed that the Seine runs through which city?'

d. Pekka väitti että [läpi minkä kaupungin] Seine virtaa? Pekka-NOM claimed that through which-GEN city-GEN] Seine-NOM runs 'Pekka claimed that the Seine runs through which city?'

Examples (33) and (34) signal an important generalization. In Finnish, a sentence produces an interrogative if and only if all wh-movement operations take place, regardless of the movement domain. If any of these operations fail to occur, the result is an echo-interpretation.

${ }^{13}$ In Finnish, the echoed wh-phrase is usually prosodically emphasised; this is not marked in the examples. 


\subsubsection{Reconstruction in both domains}

$\mathrm{A}^{\prime}$-movement is said to "reconstruct" for reflexive binding. This means that the reflexive anaphor can be interpreted "as if" it occupied the base position or one of its intermediate positions. This phenomenon is illustrated in examples $(35 \mathrm{a}-\mathrm{b})$. The third person possessive suffix (glossed as PX) attached to the noun head within a PP refers to the direct object argument, and the emerging coreference is marked by subscript $i$. This is one way of constructing reflexive anaphors in Finnish (Vainikka 1989; Trosterud 1993). Example (35b) shows that such binding is not affected by $\mathrm{A}^{\prime}$-movement triggered by the question particle $-k O$, although $\mathrm{A}^{\prime}$-movement tampers with the c-command requirement between the antecedent and the reflexive.

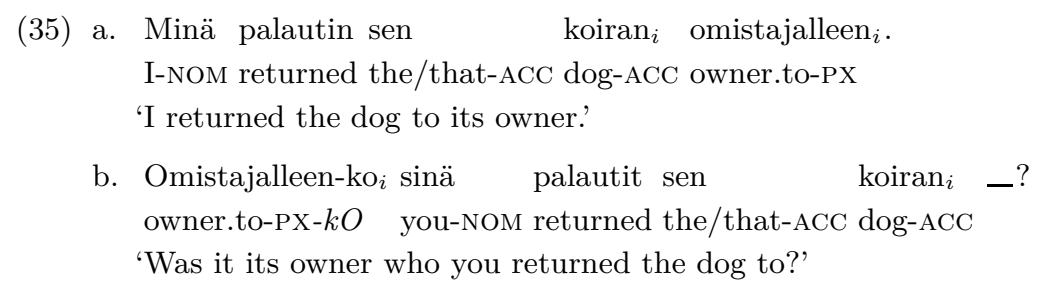

Examples (36a-b) show that secondary movement within an adverbial clause reconstructs in the same way as primary movement (see also Huhmarniemi 2012).

(36) a. [Palautettuani sen $\operatorname{koiran}_{i}$ omistajalleen $\left._{i}\right]$ minä menin kotiin. return-TUA-PX the/that-ACC dog-ACC owner.to-PX I-NOM went home.to 'After returning the dog to his owner, I went home.'

b. [Omistajalleen-ko ${ }_{i} \operatorname{koiran}_{i}$ palautettuasi $\left.{ }_{-i}\right]$ sinä menit kotiin? owner.to-PX-kO dog-ACC return-TUA-PX you-NOM went home.to 'Was it his owner who you returned the dog to before going home?'

Reconstruction is therefore a property exhibited by primary movement and, when suitable circumstances arise, also by secondary movement.

\subsubsection{Movement and scope in both domains}

The previous section considered the interpretation of reflexive anaphora. We will now consider quantifier scope assignment. As is well-known, overt movement can affect scope, and some aspects of semantic interpretation are determined at the base position while others are determined at the landing site. In the following, we provide examples of secondary movement 
that introduces new readings for quantifier expressions as well as scope reconstruction effects. Again, we will first present examples on quantifier scope changes in primary domains and propose that secondary movement of quantificational elements produces similar scope changes.

Scope reconstruction effects can be observed in examples (37) below. In (37a), the numeral kolme, 'three', is interpreted as being within the scope of the quantifier jokainen, 'every'. This reading is also available in example (37b), which involves the preposing of the numeral.

(37) a. Pekka väitti että jokainen oppilas luki kolme kirjaa.

Pekka claimed that every student read three book

'Pekka claimed that every student read three books.' $\forall>3,3>\forall$

b. [Montako kirjaa] Pekka väitti että jokainen oppilas luki _?

how many book Pekka claimed that every student read

'How many books did Pekka claim that every student read?' $\forall>$ num, num $>\forall$

In contrast, if the phrase that contains the numeral is base-generated within the matrix clause, as in (38a), it cannot be within the scope of the universal quantifier jokainen, 'every'. Example (b) shows that the wh-movement within the matrix clause does not affect the scope of the universal quantifier within the embedded clause.

(38) a. Pekka väitti kolmelle opettajalle että jokainen oppilas piti kirjasta.

Pekka claimed three.to teacher.to that every student liked book

'Pekka claimed to three teachers that every student liked the book.'

$3>\forall, * \forall>3$

b. Kuinka monelle opettajalle Pekka väitti _

how many.to teacher.to Pekka claimed

että jokainen oppilas piti kirjasta?

that every student liked book

'To how many teachers did Pekka claim that every student liked the book?'

num $>\forall, * \forall>$ num

Example (37) above thus shows that the numerical expression reconstructs. However, if the numeral was not within the scope of the universal to begin with, as in (38), wh-movement has no effect on the interpretation of the scope. In the following, the reconstruction effect is demonstrated for wh-movement within an adverbial clause. Example (39) contains an adverbial clause which shares at least the basic structure of the finite clause in examples (37a-b) above. In (39a), the numeral is within the scope of the quantifier jokainen, 'every'. This reading is also available in (39b), which involves secondary wh-movement of the phrase that contains the 
numeral. ${ }^{14}$ These examples thus demonstrate that secondary movement within an adverbial clause may reconstruct to the trace position.

(39) a. Opettaja valehteli [väittämällä että jokainen oppilas luki kolme kirjaa]. teacher lied claim-MALLA that every student read three book-PAR 'The teacher lied by claiming that every student had read three books.'

b. [Montako kirjaa väittämällä että jokainen oppilas luki _ ] how many book-PAR claim-MALLA that every student read

opettaja valehteli $\_$?

teacher-NOM lied

'How many books did the teacher lie that every student had read?'

num $>\forall, \forall>$ num

Scope changes caused by secondary movement can also be attested within Finnish DPs, see Hakulinen et al. (2004, 572) and Huhmarniemi $(2012,152)$. For instance, when a possessor that contains a universal quantifier occurs below a numeral, as in (40a), the numeral has a wide scope over the universal quantifier. If the possessor is raised to the edge, as in (40b), both wide and narrow scope readings are available for the universal quantifier. ${ }^{15}$

(40) a. Minä luin [DP kaksi [DP kaikkien sadunkertojien] lempitarinaa].

I-NOM read two all-GEN story-tellers-GEN favourite-story-PAR

'I read the two favourite stories of every story teller.' $\quad 2>\forall,{ }^{*} \forall>2$

b. [DP [DP Kaikkien sadunkertojien-ko] kaksi — lempitarinaa] sinä luit? all-GEN story-tellers-GEN- $k O$ two favourite-story-PAR you-NOM read

'Did you read every story teller's two favourite stories?' $\quad 2>\forall, \forall>2$

A similar scope shift can be observed in connection with adjectival phrases modifying a nominal head. In (41a), the numeral is embedded inside a possessor that occurs below an adjective phrase. Only the reading where two students conduct a joint project is available. However, in (41b), in which the possessor has been raised above the AP, the quantifier receives an additional wide scope reading.

${ }^{14}$ Example sentence (39b) involves long-distance movement from a finite complement clause to the edge of the adverbial. Not all speakers of Finnish accept this type of movement.

15 Both readings are attained because moved quantificational arguments reconstruct: in (40b), the DP containing the universal quantifier can be interpreted either above or below the numeral. On the other hand, the unmoved free morpheme, the numeral, takes necessarily a wide scope in (40a). 
(41) a. Pekka ihmetteli [DP toivotonta [DP kahden opiskelijan] projektia].

Pekka-NOM marvelled hopeless-PAR two-GEN student-GEN project-PAR

'Pekka marvelled at two students' hopeless project.' 1 project/*2 projects

b. [DP [DP Kahden opiskelijan-ko] toivotonta _ projektia] Pekka ihmetteli? two-GEN student-GEN- $k O$ hopeless-PAR project-PAR Pekka-NOM marvelled

'Was it two student's hopeless project that Pekka marvelled at?' 1 project/2 projects

The DP-internal movement of quantifier expressions thus provides new readings for universal quantifiers and numerals.

The fact that secondary movement triggers scope shifts is quite important because it shows that such scope shifts are not a privilege of primary operations. In order to see what we take the implication to be, consider the claim made by Chomsky $(1995 ; 2000)$ that A'-movement involves a "duality of semantics" system. According to this view, UG partitions phrase structure into two blocks: one for a generalized argument structure, tense, aspect and the like, and another for the scope-discourse properties that are associated with the left edge. $\mathrm{A}^{\prime}$-movement implements the latter, while first-merge implements the former. Our stand is that the "duality of semantics" system is in operation both in primary domains and in secondary domains (see section 4).

The observations in this section thus suggest that secondary movement introduces scope changes within the secondary domain. Note that we do not wish to claim that movement takes place "in order" to implement scope taking. Our claim is that secondary movement leads to scope changes. For instance, the data presented here is compatible with approaches where scope changes are seen as by-products of movement, as has been proposed by Szabolcsi (1997) for Hungarian. According to Szabolcsi, quantifiers move to designated structural positions to check features in overt syntax, and this movement produces scope-changes for quantifier expressions.

\subsubsection{Multiple wh-questions with pair-list readings}

Another example of a scope shift that takes place in secondary movement concerns multiple questions with a pair-list reading. The pair-list interpretation in Finnish multiple $w h$-questions is generated by suffixing the $w h$-in situ element with a clitic -kin. The wh-in situ element must occur within the scope of another wh-element. We call the -kin-particle in this context a "pair-list generator". 16

16 The particle -kin can be attached to other elements than wh-elements, such as a DP in Pekka-kin. In this context, the particle can be translated as 'also' or 'too', thus 'also Pekka'.

Acta Linguistica Hungarica 60, 2013 
(42) Mitä Pekka antoi kenelle-kin?

what-ACC Pekka-NOM gave who.to-kin

'What did Pekka give to whom?'

(pair-list only)

This pair-list generator bleeds A'-movement (Huhmarniemi \& Vainikka 2010), as the examples in (43) indicate: the wh-element with the -kinparticle does not reconstruct to its base position. Only one wh-phrase moves in Finnish multiple questions, and the same holds for multiple questions involving the -kin-particle.

(43) a. *Minkä-kin Pekka antoi — kenelle ? what-ACC-kin Pekka-NOM gave who.to

b. ${ }^{*}$ Kenelle-kin Pekka antoi minkä _? who.to-kin Pekka-NOM gave what-ACC

The same scope phemonenon can be observed in secondary domains (Huhmarniemi 2012, 213). In sentence (44b), the goal argument has been moved to the edge over the direct object, thus to a position where it serves as a correlate for the wh-in situ. Question (44b) has only the pair-list reading.

(44) a. Berlusconi nukahti [annettuaan lahjan tytöille].

Berlusconi-NOM fell.asleep give-TUA-PX present-ACC girls.to

'Berlusconi fell asleep after giving a present to the girls.'

b. [Minkä annettuaan _ kenelle-kin] Berlusconi nukahti _ ? what-ACC give-TUA-PX who.to-kin Berlusconi-NOM fell.asleep 'After giving what to whom did Berlusconi fall asleep?'

As predicted, it is impossible to ask either (45a) or (b).

(45) a. *[Minkä-kin annettuaan _ kenelle] Berlusconi nukahti _ ? what-ACC-kin give-TUA-PX who.to Berlusconi-NOM fell.asleep

b. ${ }^{*}[$ Kenelle-kin annettuaan minkä _ $]$ Berlusconi nukahti _? who.to-kin give-TUA-PX what-ACC Berlusconi-NOM fell.asleep

Unlike many quantifier expressions, Finnish multiple questions with a pair list reading do not reconstruct in $\mathrm{A}^{\prime}$-movement. We have proposed in this section that this property holds true for both primary and secondary movement. 


\subsubsection{Weak crossover in both domains}

We will next turn to investigate the weak crossover phenomenon. Weak crossover denotes a situation where a moved wh-phrase cannot bind a pronoun to its right (Postal 1971). Example (46a) illustrates weak crossover in English, and example (46b) shows weak crossover in Finnish. Example (46c) presents a contrast where weak crossover apparently disappears when the pronoun tämä, 'this', is used instead of hän, 'he/she. ${ }^{17}$

(46) a. ${ }^{*} \mathrm{Who}_{i}$ did his ${ }_{i}$ mother see _?

b. ${ }^{*}$ Kenet $_{i}$ hänen $i$ äitinsä näki _?

who-ACC his/her mother-NOM-PX saw

c. Kenet ${ }_{i}$ tämän $_{i}$ äiti näki _?

who-ACC this-GEN mother-NOM saw

'Who was seen by his/her mother?'

The weak crossover effect is generated by wh-movement within the primary domain. We will show that weak crossover takes place in secondary wh-movement within adverbial clauses. As a preliminary to our argument, example (47b) shows that the weak crossover effect is also present between the direct object and the indirect object inside a primary domain (thus the finite clause).

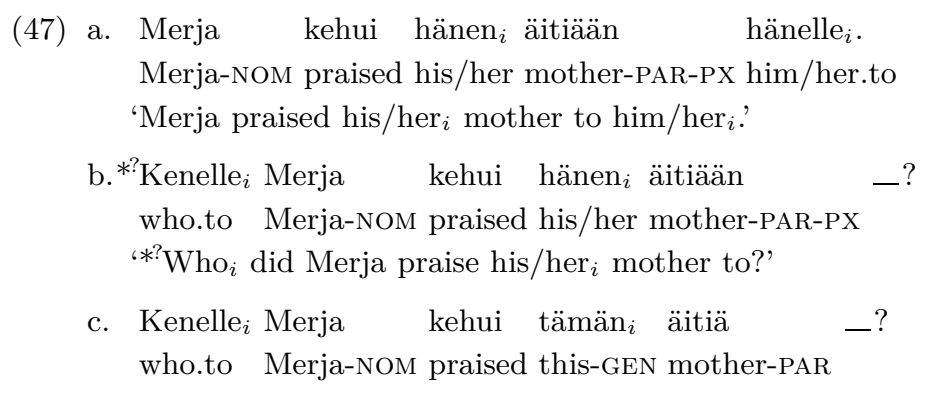

We will show that primary and secondary domains behave equivalently with respect to weak crossover; even the referring properties of the pronominal tämä, 'this', are the same. Consider sentence (48a), which contains an adverbial clause that hosts a direct object and a PP. When the PP is moved to the edge of the adverbial clause, as in (b), the wh-phrase cannot

17 The pronoun täm $\ddot{a}$ is here translated as 'this', to emphasize the distinction from the pronoun hän, 'he/she'. In the contexts exemplified here, the pronoun tämä refers like personal pronouns and does not take a non-human antecedent. Why, exactly, it does not obey the weak crossover rule will remain a mystery. 
bind the pronoun to its right. The pronoun tämä in example (c) displays the same contrast that we observed in the finite clause (47c) above.

$$
\begin{aligned}
& \text { (48) a. Merja liioitteli [kehuessaan hänen } \left.{ }_{i} \text { äitiään hänelle }{ }_{i}\right] \\
& \text { Merja-NOM exaggerated praise-ESSA-PX his/her mother-PAR-PX s/he.to } \\
& \text { 'Merja exaggerated when she was praising his/her }{ }_{i} \text { mother to him/her }{ }_{i} \text { '. }
\end{aligned}
$$

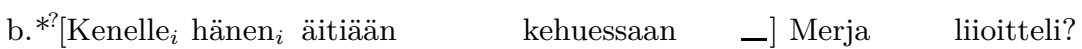

$$
\begin{aligned}
& \text { who.to his/her mother-PAR-PX praise-ESSA-PX Merja-NOM exaggerated } \\
& \text { c. [Kenelle } \left.{ }_{i} \text { tämän äitiä kehuessaan _ }\right] \text { Merja liioitteli? } \\
& \text { who.to this-GEN mother-PAR praise-ESSA-PX Merja-NOM exaggerated } \\
& \text { 'To whom did Merja exaggerate when praising his/her mother?' }
\end{aligned}
$$

We therefore witness the weak crossover effect in a secondary domain. This fact is of special interest, because weak crossover has been used as a diagnostic for A'-movement in contrast to A-movement (Lasnik \& Stowell 1991; Rizzi 1997). In other words, if a movement operation shows the weak crossover effect, it is attributed the status of $\mathrm{A}^{\prime}$-movement. However, while this diagnostic has normally been used to sort out operations within the primary domain, here we observe the same contrast in a secondary domain. Furthermore, the pronoun täm $\ddot{a}$, 'this', behaves identically in primary and secondary domains, avoiding the weak crossover effect. Consequently, it must be the same type of $\mathrm{A}^{\prime}$-movement that is at work.

\subsubsection{Resumptive prolepsis}

Certain restrictions on movement can be "circumvented" in Finnish by a resumptive strategy called "resumptive prolepsis", following the terminology of Salzmann (2006). In Finnish, primary A'-movement leaves a gap behind, and the same is true of secondary movement. In resumptive prolepsis, a relative pronoun (or a wh-phrase) forms a dependency with a coreferential resumptive pronoun, as in example (49) below. In Finnish resumptive prolepsis, the relative pronoun (or the wh-phrase) is always in the elative case, regardless of the thematic role or form of the coreferential resumptive pronoun. ${ }^{18}$

\footnotetext{
18 The proleptic strategy thus differs from ordinary resumptive pronouns in that the relative pronoun is not in the same form as the resumptive pronoun. We do not assume any particular implementation of these constructions in this paper (for discussion, see Salzmann 2006).
} 
(49) Laki, josta ${ }_{i}$ tiedettiin että $\mathrm{se}_{i}$ ei tule koskaan voimaan law which-ELA knew-PASS-PAST that it-NOM not become ever effective 'a law, of which it was known to have no chance of entering into force'

Examples (50a-b) illustrate resumptive prolepsis for Finnish wh-questions. Example (50a) shows that the subject argument cannot be extracted from a finite complement clause in Finnish (Huhmarniemi 2012, 97). This construction is possible, however, if the wh-phrase is in the elative case and the pronoun substitutes for the gap, as in (50b).

(50) a. *Kuka Merja kuuli että — ei tulisikaan? who-NOM Merja-NOM heard that not arrive.would

b. Kenestä ${ }_{i}$ Merja kuuli että hän $n_{i}$ ei tulisikaan? who.ELA Merja-NOM heard that s/he-NOM not arrive.would 'Who did Merja hear would not arrive?'

To examine whether a similar proleptic strategy is available in the context of secondary movement, we request examples in which some known constraint on movement prevents secondary movement from applying, but where the proleptic construction can be used as a repair tool. Example (51a) shows that the nominative subject cannot be extracted out of the finite complement to the edge of the containing adverbial clause. Nonetheless, the sentence can be salvaged by using the co-referring pronoun inside the adverbial (b).

(51) a. *[Kuka kuullessaan että — ei tulisikaan] Merja huolestui? who-NOM hear-ESSA-PX that not come.would Merja-NOM got worried

b. [Kenestä ${ }_{i}$ kuullessaan että hän $n_{i}$ ei tulisikaan] Merja huolestui? who.ELA hear-ESSA-PX that s/he-NOM not come.would Merja-NOM got worried 'Who did Merja hear that would not come and got worried?'

This proleptic construction is also available in other types of adverbial clauses. Example (52) shows an analogous pair of the MA-infinitive which, likewise, occupies the sentential adjunct position.

(52) a. *[Kuka kuvittelemalla että — tulisi juhliin] Merja piristyi? who-NOM imagine-MALLA that come.would party.to Merja-NOM cheered up

b. [Kenestä ${ }_{i}$ kuvittelemalla että hän ${ }_{i}$ tulisi juhliin] Merja piristyi? who.ELA imagine-MALLA that s/he-NOM come.would party.to Merja-NOM cheered up 'Who did Merja imagine that would come to the party and cheered up?' 
Much like in a primary domain, the proleptic construction can save the expression from an island violation. Interestingly, the secondary domain that involves the proleptic construction will be treated as a "normal" interrogative phrase from the perspective of the primary movement.

\subsubsection{Parasitic gaps in both domains}

We will next turn to another property of $\mathrm{A}^{\prime}$-movement that concerns the relation between the moved element and the position left behind: parasitic gaps. A parasitic gap is licensed by the presence of another gap (Engdahl 1985). Examples (53), (54) and (55) illustrate parasitic gapping in English and Finnish primary movement. Notice how primary wh-movement of the direct object licenses a direct object gap inside an adjunct phrase in the examples marked (b).

(53) a. Did John sell the book without reading it/*_?

b. Which book did John sell _ without reading it/_?

(54) a. Pekka alkoi deittailla erästä tyttöä [heti tavattuaan hänet/*_]. Pekka-NOM started dating one-PAR girl-PAR soon meet-TUA-PX her 'Pekka started dating a girl soon after meeting her.'

b. Ketä Pekka alkoi deittailla — [heti tavattuaan hänet/_]. who-PAR Pekka-NOM started dating soon meet-TUA-PX her 'Who did Pekka start dating soon after meeting her?'

(55) a. Pekka deittaili erästä tyttöä netissä [näkemättä häntä/*_]. Pekka-NOM dated one-PAR girl-PAR internet.in see-MATTA her 'Pekka dated one girl over the Internet without seeing her.'

b. Ketä Pekka deittaili — netissä [näkemättä häntä/_]? who-PAR Pekka-NOM dated Internet.in see-MATTA her 'Who did Pekka date over the Internet without seeing her?'

Furthermore, a single primary movement is able to license two parasitic gaps within secondary domains:

(56) a. Pekka teki vaikutuksen tyttöön Pekka-NOM made impression-ACC girl.to [saamalla hänet/* — ystäväkseen vain kuuntelemalla häntä /?*_]. get-MALLA her friend.to-PX just listen-MALLA her

'Pekka impressed a girl by becoming friends with her just by listening to her.' 
b. Keneen Pekka teki vaikutuksen -

who.to Pekka-NOM made impression-ACC

[saamalla hänet/_ ystäväkseen vain kuuntelemalla häntä /_]?

get-MALLA her friend.to-PX just listen-MALLA her

'Who did Pekka impress by becoming friends with her just by listening to her?'

In the following variation of (56), a secondary movement operation licenses a parasitic gap inside the embedded secondary domain. Consider first sentence (57a); here the non-finite clause contains an adverbial clause. This adverbial clause does not allow extraction, but parasitic gapping is possible. In this construction, the $w h$-phrase occurs within the pied-piped non-finite clause. Therefore, the whole parasitic gapping is constructed within the pied-piped phrase. Example (c) provides a similar construction for a relative clause.

(57) a. [Kenet saamalla — ystäväkseen [pelkästään kuuntelemalla häntä / _]

who-ACC get-MALLA friend.to-PX just listen-MALLA her

Pekka teki vaikutuksen?

Pekka-NOM made impression-ACC?

'Who did Pekka become friends with just by listening to her and thus made an impression?'

b. Tuo on se tyttö, [jonka saamalla ystäväkseen

that is the girl who-ACC get-MALLA friend.to-PX

[pelkästään kuuntelemalla häntä /_]] Pekka teki vaikutuksen.

just listen-MALLA her Pekka-NOM made impression-ACC

'That is the girl who Pekka became friends with just by listening to her and thus made an impression.'

Parasitic gapping was the last empirical comparison of primary and secondary movement examined in this paper. Before continuing with the theoretical implications that this data bears for the theory of $\mathrm{A}^{\prime}$-movement, we would like to present a theoretical point that concerns the scope of the data presented in the previous sections.

\subsubsection{Theoretical issues}

It is often claimed that secondary movement performs a "supporting" role for primary movement. Perhaps the clearest motivation for this intuition comes from successive-cyclic $\mathrm{A}^{\prime}$-movement through intermediate positions (Chomsky 1973). There is a substantial body of literature which either argues or assumes that before a wh-element reaches its final scope position, it must occupy several intermediate specifier positions. Let us assume that 
this is correct. However, the assumption that these movement steps occur in anticipation of the final primary movement steps leads to a lookahead problem: which property of the derivation triggers the intermediate movement operations when the final criterial position is not yet part of the structure (cf. Bošković 2007; Stroik 2009)? ${ }^{19}$

We think that it is possible to solve this problem if we assume that intermediate positions are not occupied "in order to" support the final primary movement step. Our hypothesis that primary movement $=$ secondary movement specifically predicts this not to be the case: whatever the primary movement is "for" will also apply to secondary movement, and vice versa. If primary movement is triggered by a local factor - a probe, if you will - and not in anticipation of later computation, then secondary movement must have the same characteristics.

A useful guideline is to look for maximally general principles. This leads to the following question: which type of movement, primary or secondary, represents the general case? So far linguists have assumed that the burden falls upon primary movement. But secondary movement takes place within several types of phrases, while primary movement is (presumably) triggered only at the CP-level. To develop this point more concretely, let us examine some Finnish constructions again. As we saw earlier in (9a) and (25b), Finnish DPs contain an edge position for wh-movement, and the same is true for PPs (examples (9b) and (25a)).

In addition, several types of adverbial clauses contain an edge position. We already saw in example (9c) that a type of adverbial clause, temporal construction, hosts an edge position. The following examples illustrate what is referred to as "rationale construction": ${ }^{20}$

(58) Non-finite clauses (adverbials)

a. Pekka osti omenoita [valmistaakseen piirakan]

Pekka-NOM bought apples-PAR cook-KSE-PX pie-ACC

'Pekka bought apples in order to bake a pie.'

b. [Minkä valmistaakseen _] Pekka osti omenoita _?

what-ACC cook-KSE-PX Pekka-NOM bought apples-PAR

'In order to prepare what did Pekka buy some apples?'

19 In pied-piping contexts, this problem is discussed by Heck (2008, 201-206) and Cable (2010b, 176-181). The lookahead problem is taken into account in both models.

${ }^{20}$ For three more types of adverbial clause with an edge position, see Huhmarniemi (2012, 188 ex. (369), 191 ex. (376), 194 ex. (383)); and for three types of non-finite complement clause with an edge p.197, ex. (390). Finally, two types of non-finite complement clause do not host an edge position ibid., 199, 204. 
Furthermore, both the adjective and adverb phrases contain an edge position that hosts, among others, wh-phrases. In example (59a), the wh-phrase occurs inside a participial phrase that modifies the adjectival head. In (b), the adjectival attribute contains a $w h$-phrase as a genitive pre-modifier. Finally, in (60), the intensifier at the edge of the adverb phrase triggers pied-piping.

(59) Adjectival phrase

a. [DP [AP Kenen korjaamaa] polkupyörää] Pekka kehui _?

who-GEN fixed-PAR bicycle-PAR Pekka-NOM praised

'The bicycle fixed by whom did Pekka praise?' b. [[AP [DP Minkä
which-GEN dress-GEN colored-ACC armchair-ACC Pekka-NOM bought

'The colour of which dress was the armchair that Pekka bought?'

(60) Adverb phrase

[Kuinka kauniisti] Pekka lauloi _ ?

how beautifully Pekka-NOM sang

'How beautifully did Pekka sing?'

The fact that secondary movement targets the edges of several types of phrases, whereas primary movement targets only the edge of finite CPs, leads us to the conclusion that it must be a mistake to put all resources into modelling primary movement, while thinking that the "supporting" secondary movement somehow takes care of itself.

We wish to conclude this section by considering some persistent objections to our conclusion that primary and secondary movement are equivalent. The data on Finnish primary and secondary movement leave room for a "disjunctive" hypothesis of the following kind. While the facts indicate that primary and secondary operations are implemented by the same mechanism, it is possible, in theory, that these operations are motivated by different properties in the primary and secondary domains. This hypothesis is disjunctive in that it proposes two unrelated explanations for one phenomenon. Stated in other words, two distinct causes are posited for one grammatical operation.

We feel quite strongly that this is an unnatural way to analyse the data. The probability that two distinct causes produce what amounts to the exact same effects is low compared to the probability that they are produced by the same cause. Parsimony alone suggest a unified analysis.

The objection has been elaborated further in the following way. True, the data may show that primary and secondary domains involve the same 
movement operation, but this point is altogether negligible. What the data does not show (so the objection goes) is that the triggers (causes) are the same. In other words, perhaps the triggers differ but the operation is the same? There are two reasons why we think this objection is not compelling. The first reason it that in Finnish, no matter where the operation takes place, whether in a primary or a secondary domain, the triggers are the same. We have not succeeded in drawing a distinction between primary and secondary triggers, so the objection remains speculative. Nevertheless we are certainly sympathetic to the possibility that a distinction will eventually be found, or that a specific trigger will be revealed for primary movement.

But suppose, contrary to our proposal, that the trigger for primary movement were A and the trigger for secondary movement were B. Suppose, in addition, that these were different triggers. Then it would be an accident that they both triggered the same operation and led to the exact same empirical consequences. We would be naturally inclined towards a hypothesis according to which there must be some property that both $\mathrm{A}$ and B shared for them to trigger exactly the same operation. What is then relevant is not the difference between $\mathrm{A}$ and $\mathrm{B}$ but the property $\mathrm{P}$ that they share.

Our way of thinking is not entirely without precedents. For instance, in Chomsky's minimalist theory, the common property of the triggering features is that they must be uninterpretable (Chomsky 2000; 2001). To pick up another case, consider the well-known regularity that both nouns and adjectives require of-support in order to be complemented with DPs (A book * (of) Aristoteles, fond * (of) Mary). In theory, it is possible that the of insertion operation is triggered by two distinct features of the nominal and adjective heads. Perhaps it is the N-feature for nominals and the A-feature for adjectives? Our feeling is that one is better off pursuing the well-known GB-theoretical path of searching for some commonality between nouns and adjectives, such as the Case Filter, and then postulating the same trigger for both cases.

One may still insist that there is a difference between primary movement and secondary movement: whereas primary wh-movement targets a position corresponding to genuine interrogativization, for instance a position or a phrase that can be selected as an interrogative, intermediate wh-movement does not. In other words, secondary positions occupied by wh-elements do not need to involve interrogative interpretation at all; they are merely intermediate "placeholders" of sorts. That is why Rizzi (2006), for instance, claimed that they host uninterpretable pseudo-features. This 
reasoning shows that primary and secondary domains are not identical and that, most likely, movement operations differ after all.

But we are not claiming that the primary and secondary domains are identical. A claim which says that two operations are the same does not imply that their domain of application must be identical. The same operation can of course be applied in a wide variety of circumstances. If both nouns and adjectives need of-support, say because nouns and adjectives are unable to assign Case, it does not follow by any recognizable logic that they cannot have distinguishing properties. What follows from the fact that primary domains are domains of true $w h$-features is that it cannot be this feature which underlies $\mathrm{A}^{\prime}$-movement. Plainly, it is not: focus particles, left-peripheral discourse clitics and relative pronouns engage in the same system. In addition, some languages do not require overt movement at all for the checking of the $w h$-feature.

\section{Primary/Secondary Equivalence}

This section provides a hypothesis for the implementation of primary and secondary $\mathrm{A}^{\prime}$-movement in grammar. The hypothesis is motivated by the observation that primary and secondary movement share all the relevant properties of movement in Finnish. To recapitulate, primary and secondary movement obey the edge principle, they leave a gap and the moved element c-commands the gap position; both movement types are triggered by the same properties, they involve pied-piping, island constraints, echointerpretation associated with the wh-in situ strategy, reconstruction in reflexive binding, scope interaction, weak crossover, proleptic strategy and parasitic gapping. In conclusion, then, if primary and secondary movement look exactly the same, is there any a need to make a distinction between the two? We suggest a negative answer:

(61) Primary/Secondary Equivalence (P/SE)

Primary movement $=$ secondary movement

Primary/Secondary Equivalence states that primary movement and secondary movement are two instantiations of the same underlying operation. Whatever differences they have are accidental and irrelevant to the theory of $\mathrm{A}^{\prime}$-movement, much like the difference between the Evening Star and the Morning Star is irrelevant to cosmology.

In this section we will propose a hypothesis concerning $\mathrm{A}^{\prime}$-movement and its underlying implementation in grammar by developing Chomsky's 
edge feature (EF) approach (Chomsky 2008). To begin with, consider the core case of successive-cyclic movement from a complement CP. A wh-element starts off inside an embedded CP, rises to the embedded Spec-C and continues to the matrix Spec-C, where its $w h$-feature is checked and the element is frozen in place (62).

(62) Who did John believe — that Mary saw _?

What triggers the first movement step? There is no $w h$-feature inside the embedded CP-layer. P/SE leads us to a position according to which whatever triggers the operations within the matrix $\mathrm{CP}$ must trigger the operations within the embedded CP. According to McCloskey (2002), the intermediate movement steps are triggered by "pseudo-feature" alternatives to the full features. The idea is illustrated in (63).

(63) Who did John believe _ that Mary saw _?

wh $\mathrm{C}($ 'real'-wh $) \quad \mathrm{C}($ 'pseudo'-wh $)$

Although this position comes very close satisfying $\mathrm{P} / \mathrm{SE}$, the two triggering features still differ: the secondary feature is a formal counterpart of the primary feature, the latter having a "proper" semantic interpretation. A simple correction will align this proposal with $\mathrm{P} / \mathrm{SE}$. Instead of saying that primary movement is triggered by a semantically interpreted $w h$-feature while secondary movement is triggered by a formal counterpart, we say that the difference does not matter at all for $\mathrm{A}^{\prime}$-movement. Recall that, in Finnish, $\mathrm{A}^{\prime}$-operations are triggered not only by $w h$-features but also by relativisation, contrastive focus and discourse clitics. Parsimony suggest that since all these features trigger the same operations and are eager to occupy the same left peripheral position, there is only one trigger for all of them. If that is the case, then that feature is not the wh-feature. But what feature is it?

We propose that the trigger is Chomsky's edge feature (Chomsky 2008). First, to provide some background, assume that there are two types of operations which bring new syntactic objects to the derivation: internal merge (IM) and external merge (EM). External merge is so named because it brings new elements to the syntactic object from an external source, such as from the lexicon. Internal merge, in contrast, uses material already merged with the syntactic object and re-merges it at the root. If the original element is not pronounced, IM produces the surface effects of movement. The standard assumption has been that there is a separate feature, call it EPP, which triggers IM. But if both EM and IM are forms 
of the same operation, Merge, why would IM need a separate trigger? Or shall we conclude that EM is also driven by an "EPP-feature"? Chomsky (2008, 140-141) answers both questions in the negative and suggests that $\mathrm{IM} / \mathrm{EM}$ are driven by one feature, the edge feature (EF). The edge feature is a formal property which allows a lexical element to be merged (recursively) with other constituents, such as its complement and specifier. The condition can be fulfilled by both EM and IM (EM for complements and specifiers, IM for specifiers only).

What property then determines whether the EF is satisfied by EM or IM? Chomsky proposes that the answer lies in the Conceptual-Intentional (C-I) component. The C-I component is constituted by a duality of semantics system. The first semantic component interprets the generalized argument structure specifying who did what to whom. The generalized argument structure is crafted by iterative application of EM, whereupon arguments and predicates find their places in the phrase structure. Each argument is provided a thematic role. The second semantic component interprets scope-discourse properties and is implemented by IM. No new thematic roles or thematic slots are created, and hence no new elements (apart from expletives) can be merged from an external source to obtain such roles. Instead, old elements already bearing thematic roles are recycled. Thus, movement to the left peripheral position is associated with numerous scope and discourse properties. The proposal is that it is the C-I component which dictates which operation is used to satisfy the edge feature of a given lexical item. In Chomsky's words, "Languge seeks to satisfy the duality in the optimal way, EM serving one function and IM the other" (op.cit., 141). If the edge feature of some functional head (whatever these may be) can be satisfied by IM we say, for convenience, that the functional head possesses the discourse edge feature $\mathrm{EF}^{\prime}$. The $\mathrm{EF}^{\prime}$-feature creates a specifier position for elements that are provided by IM and are potentially interpreted by the higher semantic system of C-I.

The idea is illustrated in (64), where the $\mathrm{EF}^{\prime}$ of $\mathrm{C}$ is filled by moving the $w h$-pronoun. This operation produces novel semantic properties (interrogativization, scope taking, perhaps also focus) over and above those generated by the argument structure itself.

(64) Who C did Mary see _ ?

$\mathrm{EF}^{\prime}$

We will now generalize this notion and claim that both primary and secondary IM are $\mathrm{EF}^{\prime}$-triggered, as is illustrated in (65) below. Suppose that $\mathrm{EF}^{\prime}$ targets $w h$-phrases, contrastively focused phrases, relative pronouns 
and discourse clitic phrases, all elements which can receive a particular discourse interpretation at the edge. We might say that they possess some formal mark designating them for $\mathrm{EF}^{\prime}$-probing, or we could follow Chomsky and assume that "the edge feature [...] is indiscriminate: it can seek any goal in its domain" (op.cit., 151). Seeking is implemented by means of Agree. The discourse edge feature functions as a probe, targets a goal, then moves the goal to its specifier. If the goal has interpretable features, such as wh- or focus-features, they will enter the interpretation, much like its lexical content.

(65) Who C did John believe - C Mary saw -

$$
\begin{aligned}
& w h \quad \mathrm{EF}^{\prime}+w h \quad \mathrm{EF}^{\prime} \\
& \operatorname{Agree}\left(\mathrm{EF}^{\prime}, w h\right)+\operatorname{IM}(w h)+\operatorname{Agree}\left(\mathrm{EF}^{\prime}, w h\right)+\operatorname{IM}(w h)+\operatorname{Agree}(w h, w h)
\end{aligned}
$$

Notice that the embedded C lacks the $w h$-feature, and there are no pseudowh-features either. Both the embedded CP and the matrix CP contain the same discourse edge feature $\mathrm{EF}^{\prime}$ that triggers the $\mathrm{A}^{\prime}$-operations. The wh-feature does not have a role in triggering movement. Equivalence is maintained: primary movement and secondary movement are caused by the same grammatical system, Agree $\left(\mathrm{EF}^{\prime}, w h\right)+\mathrm{IM}(w h)$. (From now on, we will illustrate our analysis by using the $w h$-feature as an example; the same analysis is meant to apply to relativisation and to discourse clitics.)

In Finnish, not only CPs but several types of phrases instantiate overt $\mathrm{A}^{\prime}$-movement to the edge: DPs, PPs, adverbial clauses and some non-finite complement clauses. We therefore claim that the highest functional head inside such phrases possesses the discourse edge feature, triggering Agree $\left(\mathrm{EF}^{\prime}, w h\right)$ and $\operatorname{IM}(w h)$. Notice that there is no agreement between $w h$-features at this stage; the $\mathrm{EF}^{\prime}$-probe seeks any element with the appropriate interpretation and/or feature constellation or, if we want to follow Chomsky, any element whatsoever (in which case interpretation is determined at the landing site). Example (66a-b) shows how this analysis applies to a DP and a PP in Finnish.

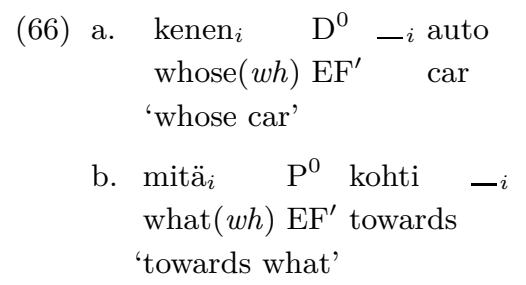


We thus propose that only primary movement is associated with genuine interrogative force. We will assume that only CPs, as they contain the force of the sentence, can bear the interrogative force feature that checks the $w h$-feature of the goal, as in (65). This assumption does not deviate from $\mathrm{P} / \mathrm{SE}$. We claim that movement results from $\mathrm{EF}^{\prime}$, but the wh-feature has a different purpose: it marks the clause as an interrogative. Wh-checking and $\mathrm{EF}^{\prime}$-checking are therefore two different mechanisms. Wh-checking ensures that an interrogative force at the matrix $\mathrm{C}$ is associated with a wh-element. The $\mathrm{EF}^{\prime}$-system regulates IM. Several factors speak in favour of these assumptions. Above all, in Finnish, the $\mathrm{EF}^{\prime}$-system is much more general in scope and targets several types of discourse-sensitive elements, such as discourse clitics. Second, there are languages and constructions where movement is not required for checking the wh-feature. In Chinese and other $w h$-in situ languages, wh-movement does not take place at all. In English, certain pied-piped phrases do not require wh-elements to move to their left edge, contrary to Finnish. This is consistent with the idea that wh-checking and $\mathrm{EF}^{\prime}$-checking are two distinct operations. Whereas wh-checking is universal, there are differences in how different languages handle the $\mathrm{EF}^{\prime}$.

Let us look at the in situ phenomenon more carefully. In the past, the $w h$-in situ phenomenon has been analysed differently depending on whether it occurs in association with primary movement or secondary movement. $\mathrm{P} / \mathrm{SE}$ forces us to rethink these assumptions. When it comes to primary movement, there are at least two main cases to consider: $w h$-in situ languages and the $w h$-in situ echo-interpretation. In a $w h$-in situ language, all wh-elements remain in situ while the sentence is (or rather can be, if suitable circumstances prevail) interpreted "as if" those elements took their scope somewhere higher in the structure (Huang 1982a;b). The following example demonstrates this for Chinese.

(67) $\mathrm{Ni}$ kanjian-le shei

you see-AsP who

'Who did you see?' (Huang 1982b, ex. 159, p. 253)

Either the $w h$-feature is checked directly by the $w h$-goal by means of Agree, or there is a covert IM. Let us assume that checking is done by Agree $(w h, w h)$ without (overt or covert) IM. ${ }^{21}$ The $w h$-feature at C functions as a probe and seeks a wh-goal. $\mathrm{C}$ does not have an $\mathrm{EF}^{\prime}$ that would require something to fill its specifier.

${ }^{21}$ Nothing we propose here will be in flat contradiction with the hypothesis that wh-checking is performed by covert movement. 
The second relevant case of the $w h$-in situ phenomenon in connection with primary movement concerns the echo-interpretation. Recall that, in Finnish, an in situ wh-phrase triggers an echo-interpretation instead a normal interrogative. If any of the secondary or primary movement steps is cancelled, an echo-interpretation is forced. Notice that Primary/Secondary Equivalence predicts these facts: if an in situ wh-element triggers an echo interpretation within a primary domain, it should do the same within a secondary domain. This is exactly what we observed in Finnish. In English, the wh-element may stay in situ within certain secondary domains (towards which city does the Seine run). The in-situ wh-element should now behave analogously to $w h$-in situ languages in that the wh-element cannot rise to the edge position within the secondary domain while it still has the force of an ordinary interrogative (compare the Chinese (67)). That, too, appears to be true: for some reason, English PPs do not have the edge position for wh-elements, and so there is no discourse edge feature at $\mathrm{P}$ either.

But if Agree can check the wh-feature without movement, why does the lack of IM trigger the echo-interpretation in Finnish? Clearly, there must be some interaction between wh-checking and IM. One possible answer is the Phase Impenetrability Condition (PIC) (Chomsky 2000). Chomsky (2008) assumes that grammatical heads triggering A'-movement to their specifier, hence grammatical heads bearing the edge feature (our $\mathrm{EF}^{\prime}$ ), are phase heads. A phase head is a head that prevents higher operations from seeing into its complement, thus making it impenetrable. Suppose, then, that the complement of a grammatical head bearing the discourse edge feature constitutes a phase in the sense of Chomsky (2000; 2008): higher probes cannot see into it. Only the phase head and its specifier are visible. Thus, in configuration (68), the higher probe $\mathrm{C}(w h)$ cannot establish Agree $(w h, w h)$ with the lower wh, because $\mathrm{H}$ makes $\alpha$ impenetrable.

(68) $\mathrm{C}(w h) \ldots[\operatorname{Spec} \mathrm{H} \quad[\alpha \ldots w h \ldots]]$

$$
\mathrm{EF}^{\prime}
$$

From this it follows that Agree $\left(\mathrm{EF}^{\prime}, w h\right)$ must be followed by $\operatorname{IM}(w h)$ if the $w h$-feature remains unchecked. ${ }^{22}$ Although an attractive hypothesis

${ }^{22}$ Let us go through the core cases to verify that these assumptions work as we want. In a language that lacks overt $w h$-movement, there are no heads with the discourse edge feature, hence the highest $w h$-probe can Agree with a wh-goal downstream. In English, an interrogative $\mathrm{C}$ has the $\mathrm{EF}^{\prime}$-feature. Without successive-cyclic movement, then, the embedded wh-goal cannot Agree with the matrix $w h$-feature and the derivation cannot create an interrogative. PPs in English are not headed by the 
(perhaps even a sound one), PIC has several problems which lead us to ultimately reject it in favor of Rizzi's relativized minimality approach (Rizzi 1990). One problem is that in Finnish, structural Case assignment does not respect the postulated phase boundaries. Agreement in the matrix clause will affect the structural Case composition inside an adverbial in Finnish regardless of whether the adverbial is headed by the $\mathrm{EF}^{\prime}$ or not. This is illustrated in the examples in (69): in the passive sentence (a), the object of the non-finite clause is in the nominative case, whereas in (b), where the verb inflects in $\phi$-features of the subject, the object is in the accusative case. The same distinction holds for pied-piped phrases (c-d). ${ }^{23}$

(69) a. Me suoritettiin tentti [lukemalla kirja].

we-NOM passed-PASS examination-NOM read-MALLA book-NOM

'We passed the examination by reading a book.'

b. $\mathrm{Me}$ suoritimme tentin [lukemalla kirjan].

We-NOM passed-1PL examination-ACC read-MALLA book-ACC

'We passed the examination by reading a book.'

c. ?[Mikä lukemalla _ $]$ me suoritettiin tentti?

what-NOM read-MALLA we-NOM passed-PASS examination-NOM

'By reading what did we pass the examination?'

d. [Minkä lukemalla _- ] me suoritimme tentin?

what-ACC read-MALLA we-NOM passed-1SG examination-ACC

'By reading what did we pass the examination?'

The $\mathrm{EF}^{\prime}$ at the edge of the adverbial phrase in examples $(69 \mathrm{c}-\mathrm{d})$ does not therefore prevent Agree relations to the complement of the phase head. Similar facts can be demonstrated for DPs, other adverbials and non-finite clauses. To accommodate the long distance Case mechanism, we propose that the $\mathrm{EF}^{\prime}$ does not make the phrase impenetrable for all Agree operations; it will only block $\mathrm{A}^{\prime}$-probing in the spirit of Rizzi's relativized

$\mathrm{EF}^{\prime}$, no movement is required and interrogativization still results. In Finnish, PPs are headed by the $\mathrm{EF}^{\prime}$, and therefore, a wh-goal inside these domains cannot be probed by a higher probe, since only the edge of these phrases (the highest head and its specifier) is visible. Movement to the Spec-P will solve this problem. If movement fails to occur at any stage, the goal becomes invisible to higher probes, and the derivation will only converge with the echo-interpretation: the wh cannot be checked and must be absent.

${ }^{23}$ It might strike some readers as surprising that in Finnish, structure Case assignment works this way, but the fact is well-known (Brattico 2009; Vainikka \& Brattico 2009; Brattico 2011; 2012a; 2013). 
minimality (Rizzi 1990). This allows structural Case assignment to penetrate $\mathrm{EF}^{\prime}$-phrases, but corretcly stops wh-probing.

Another more serious problem for the PIC derives from the observation that, in opposition to $w h$-words and relative pronouns, the yes-no question clitic $-k O$ and other discourse clitics can remain in situ within a secondary domain while still generating the appropriate discourse interpretation. Consider again example (23)/(70a). In this example, the phrase hosting the $-k O$-particle does not occupy the edge but is still able to trigger pied-piping of the containing DP. Although this construction forms a special case, it violates the PIC hypothesis because, contrary to the hypothesis, Agree seems to be able to penetrate a boundary that is headed by the $\mathrm{EF}^{\prime}$. This example can be compared to pied-piping by a contrastively focused constituent in (b). Recall that in Finnish the contrastive focus also triggers movement to the left periphery of the finite clause. As can be seen in the example, the contrastively focused phrase can escape the requirement to occupy the edge position within the secondary domain.

(70) a. [Merjan kaupukiin-ko muuttamista] sinä odotat _?

Merja's city.to- $k O$ moving-PAR you-NOM wait

'Is it Merja's move to the city that you are waiting for?'

b. [Merjan kaupunkiin muuttamista] minä odotan _!

Merja's city.to moving-PAR I-NOM wait

'I'm waiting for Merja's move to the city!'

Although these data are problematic for PIC, they do not lead to a contradiction with the approach proposed here. We will assume that the $\mathrm{EF}^{\prime}$ is a boundary for $w h$-features and relativisation but not for the other discourse features. This means that the Agree between the $\mathrm{C}$ and the $-k O$-particle can proceed past the EF'-feature. ${ }^{24}$

In sum, we propose that overt $\mathrm{A}^{\prime}$-movement is caused by the $\mathrm{EF}^{\prime}$. This feature provides an extra specifier position for a projection that is interpretable by the scope-discourse system. The discourse edge feature occupies several functional heads in Finnish. The $\mathrm{EF}^{\prime}$ will also cause rela-

${ }^{24}$ Holmberg (in press) proposes that $-k O$-particles involve two discourse features, focus and $\mathrm{Q}$, and can therefore be considered as more complex discourse entities than, for example, relative pronouns. Brattico (2012b) discusses the same data we address in the main text and draws a distinction by claiming that $w h$-words and relative pronouns are instricially variables, while discourse elements are not. Under both these hypotheses, the $\mathrm{EF}^{\prime}$ is relativised to the features involved in Agree: it constitutes a barrier for relative pronouns and $w h$-words but not for other discourse elements. 
tivized minimality effects, so that further $\mathrm{A}^{\prime}$-probing into a phrase headed by the $\mathrm{EF}^{\prime}$ is prohibited.

\section{Conclusions}

Recent theories of secondary movement can be classified according to whether they assume that secondary movement differs from primary movement. Here we put this hypothesis to the test by examining secondary movement in Finnish. It was found that secondary movement has all the properties of primary movement, including all the same triggers, constraints and effects on interpretation, which led us to conclude that there is no difference between the two. This result, if true, allows us to narrow down the theoretical possibilities in explaining A'-movement. Any theory of $\mathrm{A}^{\prime}$-movement must explain the properties of both primary and secondary domains, and, likewise, any such theory can draw data from a much richer source, thus including movement data from primary and secondary domains.

\section{References}

Bošković, Zeljko. 2007. On the locality and motivation of Move and Agree: An even more minimal theory. Linguistic Inquiry 38. 589-644.

Brattico, Pauli. 2009. Long-distance case assignment and the theory of phases. Biolinguistica Fennica Working Papers 1. 79-104.

Brattico, Pauli. 2011. Case assignment, case concord, and the quantificational case constructions. Lingua 121. 1042-1066.

Brattico, Pauli. 2012a. Case assignment and phi-agreement in Finnish. SKY Journal of linguistics 25. 29-59.

Brattico, Pauli. 2012b. Islands and operators in Finnish. Biolinguistica Fennica Working Papers 3. 1-40.

Brattico, Pauli. 2012c. Pied-piping domains and adjunction coincide in Finnish. Nordic Journal of Linguistics 35. 71-89.

Brattico, Pauli. 2013. Rethinking case assignment. In J.-M. Tirkkonen and E. Anttikoski (eds.) Proceedings of the 24th Scandinavian Conference of Linguistics. Joensuu: University of Eastern Finland, Publications of the University of Eastern Finland. Reports and Studies in Education, Humanities, and Theology 5. 37-46.

Cable, Seth. 2010a. Against the existence of pied-piping: Evidence from Tlingit. Linguistic Inquiry 41. 563-594.

Cable, Seth. 2010b. The grammar of Q: Q-particles, wh-movement, and pied-piping. Oxford: Oxford University Press. 
Chomsky, Noam. 1973. Conditions on transformations. In S. Anderson and P. Kiparsky (eds.) A Festschrift for Morris Halle. New York: Holt, Reinhart and Winston. 232286.

Chomsky, Noam. 1977. On wh-movement. In P. W. Culicover, T. Wasow and A. Akmajian (eds.) Formal syntax. New York: Academic Press. 71-132.

Chomsky, Noam. 1993. A minimalist program for linguistic theory. In K. Hale and S. J. Keyser (eds.) The view from building 20. Essays in linguistics in honor of Sylvain Bromberger. Cambridge MA: MIT Press. 1-52.

Chomsky, Noam. 1995. The minimalist program. Cambridge MA: MIT Press.

Chomsky, Noam. 2000. Minimalist inquiries: The framework. In R. Martin, D. Michaels and J. Uriagereka (eds.) Step by step: Essays on minimalist syntax in honor of Howard Lasnik. Cambridge MA: MIT Press. 89-155.

Chomsky, Noam. 2001. Derivation by phase. In M. Kenstowicz (ed.) Ken Hale: A life in language. Cambridge MA: MIT Press. 1-52.

Chomsky, Noam. 2008. On phases. In R. Freidin, C. P. Otero and M. L. Zubizarreta (eds.) Foundational issues in linguistic theory. Essays in honor of Jean-Roger Vergnaud. Cambridge MA: MIT Press. 134-166.

Coon, Jessica. 2009. Interrogative possessors and the problem with pied-piping in Chol. Linguistic Inquiry 40. 165-175.

Cowper, Elizabeth. 1987. Pied piping, feature percolation, and the structure of the noun phrase. Canadian Journal of Linguistics 32. 321-338.

Engdahl, Elisabet. 1985. Parasitic gaps, resumptive pronouns, and subject extractions. Linguistics 23. 3-44.

Grimshaw, Jane. 2000. Locality and extended projection. In P. Coopmans, M. Everaert and J. Grimshaw (eds.) Lexical specification and insertion. Amsterdam \& Philadelphia: John Benjamins. 115-133.

Hakulinen, Auli and Fred Karlsson. 1979. Nykysuomen lauseoppia [Syntax of Modern Finnish]. Helsinki: Finnish Literature Society.

Hakulinen, Auli, Maria Vilkuna, Riitta Korhonen, Vesa Koivisto, Tarja Riitta Heinonen and Irja Alho (eds.). 2004. Iso suomen kielioppi [Comprehensive Finnish grammar]. Helsinki: Finnish Literature Society.

Heck, Fabian. 2004. A theory of pied-piping. Doctoral dissertation. Universität Tübingen.

Heck, Fabian. 2008. On pied-piping: Wh-movement and beyond. Berlin \& New York: Mouton de Gruyter.

Heck, Fabian. 2009. On certain properties of pied-piping. Linguistic Inquiry 40. 75-111.

Holmberg, Anders. in press. The syntax of the Finnish question particle. In P. Svenonius (ed.) Functional structure from top to toe. Oxford: Oxford University Press.

Holmberg, Anders and Urpo Nikanne. 2002. Expletives, subjects and topics in Finnish. In P. Svenonius (ed.) Subjects, expletives, and the EPP. Oxford: Oxford University Press. $71-106$.

Horvath, Julia. 1997. The status of "wh-expletives" and the partial wh-movement construction of Hungarian. Natural Language \& Linguistic Theory 15. 509-572.

Horvath, Julia. 2006. Pied-piping. In M. Everaert and H. van Riemsdijk (eds.) The Blackwell companion to syntax. Malden MA \& Oxford: Blackwell. 569-630. 
Huang, Cheng-Teh James. 1982a. Logical relations in Chinese and the theory of grammar. Outstanding Dissertations in Linguistics, New York: Garland.

Huang, Cheng-Teh James. 1982b. Move wh in a language without wh movement. Linguistic Review 1. 369-416.

Huhmarniemi, Saara. 2009. Extraction islands in Finnish. Biolinguistica Fennica Working Papers 1. 21-78.

Huhmarniemi, Saara. 2012. Finnish A'-movement: Edges and Islands (Studies in Cognitive Science 2). Helsinki: University of Helsinki.

Huhmarniemi, Saara. 2013. Internal wh-movement in Finnish. In J.-M. Tirkkonen and E. Anttikoski (eds.) Proceedings of the 24th Scandinavian Conference of Linguistics. Joensuu: University of Eastern Finland. 71-79.

Huhmarniemi, Saara and Anne Vainikka. 2010. Multiple wh-questions and syntactic islands in Finnish. In Proceedings of Congressus XI Internationalis Fenno-Ugristarum (FU11). Piliscsaba 2010, Budapest, Hungary: Reguly Társaság. 227-233.

Kayne, Richard S. 1994. The antisymmetry of syntax. Cambridge MA: MIT Press.

Koopman, Hilda and Anna Szabolcsi. 2000. Verbal complexes. Cambridge MA: MIT Press.

Lasnik, Howard and Tim Stowell. 1991. Weakest crossover. Linguistic Inquiry 22. 687720 .

McCloskey, James. 2002. Resumption, successive cyclicity, and the locality of operations. In S. D. Epstein and D. T. Seely (eds.) Derivation and explanation in the Minimalist Program. Malden MA \& Oxford: Blackwell. 184-226.

Nevis, Joel Ashmore. 1988. Finnish particle clitics and general clitic theory. New York \& London: Garland Publishing.

Postal, Paul. 1971. Cross-over phenomena. New York: Holt, Rinehart and Winston.

Riemsdijk, Henk van. 1985. On pied-piped infinitives in German relative clauses. In J. Toman (ed.) Studies in German grammar. Dodrecht: Foris. 165-192.

Rizzi, Luigi. 1990. Relativized minimality. MIT Press: Cambridge MA.

Rizzi, Luigi. 1997. The fine structure of the left periphery. In L. Haegeman (ed.) Elements of grammar. Dordrecht: Kluwer. 281-337.

Rizzi, Luigi. 2006. On the form of chains: Criterial positions and ECP effects. In L. L.-S. Cheng and N. Corver (eds.) Wh-movement: Moving on. Cambridge MA: MIT Press. 97-133.

Ross, John Robert. 1967. Constraints on variables in syntax. Doctoral dissertation. MIT.

Salzmann, Martin. 2006. Resumptive prolepsis: A study in indirect A'-dependencies. Doctoral dissertation. University of Leiden.

Stroik, Thomas S. 2009. Locality in minimalist syntax. Cambridge MA: MIT Press.

Szabolcsi, Anna. 1997. Strategies for scope taking. In A. Szabolcsi (ed.) Ways of scope taking (SLAP 65). Dordrecht: Kluwer. 109-154.

Trosterud, Trond. 1993. Anaphors and binding domains in Finnish. In A. Holmberg and U. Nikanne (eds.) Case and other functional categories in Finnish syntax. Mouton de Gruyter: Berlin \& New York. 225-243.

Vainikka, Anne. 1989. Deriving syntactic representations in Finnish. Doctoral dissertation. University of Massachusetts Amherst. 
Vainikka, Anne and Pauli Brattico. 2009. The Finnish accusative: Long distance case assignment by phi-agreement. Manuscript submitted for publication.

Vilkuna, Maria. 1989. Free word order in Finnish: Its syntax and discourse functions. Helsinki: SKS.

Vilkuna, Maria. 1995. Discourse configurationality in Finnish. In K. É. Kiss (ed.) Discourse configurational languages. Oxford: Oxford University Press. 244-268.

Webelhuth, Gert. 1992. Principles and parameters of syntactic saturation. Oxford: Oxford University Press. 